\title{
The Influence of Parenting Style Toward Child's Moral Values Development
}

\author{
La Jeti \\ Early Childhood Education Departement \\ Muhammadiyah Buton University \\ Baubau, Indonesia \\ lajeti469@gmail.com
}

\begin{abstract}
This research aimed to know the influence of parenting style on the child's moral values development. This research used a quantitative approach. The kind of this research is ex-post facto. The population in this research consisted of $\mathbf{1 5 0}$ parents and 150 children. This research was conducted at Raudhatul Athfal in Murhum District of Baubau City. Data collected used questionnaire and observation sheets. Data analysis techniques in this research used statistical regression. Based on the data analysis technique indicated the result of authoritarian parenting style had a positive and significant influence on the child's moral values development proved with coefficient regression as much as 1.966 and significance of $0.023<0.05$. Authoritative parenting style had positive, but not significant influence on the child's moral values development proved with coefficient regression as much as 0.433 and significance as much as $\mathbf{0 . 0 6 5}>\mathbf{0 . 0 5}$. Permissive parenting style had positive, but not significant influence on the child's moral values development proved with coefficient regression as much as 1.128 and significance as much as $0.103>0.05$.
\end{abstract}

Keywords - Parenting style, child moral values development

\section{INTRODUCTION}

Early childhood education involves all actions taken by educators and parents in the process of caring, and provision of education to children. Parents and educators should create a good environment, where children could explore and gain experience from interactions with their environment through observing, imitating, and experimenting with their full potential. The results of the study [1], concluded that fulfilling the needs of children, in this case, the social needs of children, people always make maximum efforts to meet these needs, such as providing time to children every week, both in the form of recreation and family visits that are social. Fulfillment of psychological, physical, and social needs for children is a basic need that needs attention.

Early childhood is a sensitive period, to gain the various information in their environment. At this age, the child has an intellectual capacity of $80 \%$. It means that the child has a strong catching power against the information he obtained. An early child called it Absorbent Mind fast absorbing thought. Information that enters through the child's senses is quickly absorbed into the brain. The absorption capacity of a child's brain is similar to a sponge that quickly absorbs water. For this reason, educators should not be wrong in giving concepts to children.

Pestalozzi said: "parents are the best teacher for his children." It means that the family provides the basis for the formation of behavior, character, morals, and education for children from an early age [2]. While John Locke said "the child was born like the blank tablet" means that children are born like blank paper, for the environment children will shape it into a good person. Parental involvement is a degree shown by parents regarding interest, knowledge, and willingness to play an active role in children's daily activities [3].

Providing education for children from early childhood is very important because it is a big idea in the future. Every parent says that a child is an invaluable investment. Child's future success is pride for his parents [4]. However, the success of a child will not be achieved if a good education does not support it. Therefore, it fits for parents to prepare their children's education from an early age to develop all the potential that exists in the child. Parents are expected to give attention and affection and show good behavior or positive parenting so that children feel a harmonious relationship with people. Parents become role models for children [5], explaining that parenting is a parent's behavior in disciplining children and making children accountable through guidance and assertiveness.

Authoritarian parenting style is a limiting and punitive parenting style; parents need their children to obey their parents and respect them [6]. Authoritarian parents place strict boundaries and controls on children and do not provide opportunities for children to consult. Children of authoritarian parents are often unhappy, afraid and anxious, lacking skills, and having problems communicating with people surrounding it. It is consistent with the results of the study), concluding that parents who cared with authoritarian parenting can make children less social. Ref [7] concluded that parents who care for authoritarian parenting have a negative relationship. Children with authoritarian parenting tend to have behavioral problems and are not achieving.

While parents with authoritative parenting tend to encourage children to be independent, but still provide limits and control over children's actions. Parents always dialogue Verbally with children and are warmed. Children who are 
cared for with authoritative parenting have a sense of selfconfidence, achievement-oriented and able to build communication with those around them. Ref [8] concluded that authoritative parenting provides a positive influence on children's emotional and behavioral problems. Ref [9] concluded that parents with authoritative parenting are more open, by giving children confidence, it is expected that children can be more independent. The way done by parents in instilling character values is by providing exemplary of parents.

Parents with permissive parenting patterns are parenting styles where parents are very involved with children, but lack the demands or control of children. Children who are cared to this parenting pattern will be egocentric, disobedient, and difficult in relationships with peers. It is consistent with the ref [10], concluding that the results of permissive parenting have a negative influence on children's behavior. With permissive parenting, children have behavioral problems and tendencies to experience conflict with their peers. Ref [11] stated that concluding parents with permissive parenting had a negative influence on children's self-regulation.

Moral development is an activity that deals with other people who need socialization in behavior, learning to play a behavioral role, and efforts to develop moral values that are worthy of being accepted by others or peers. Ref [12] explains that moral development is a moral behavior code or social group rules. Moral development in early childhood is directed at developing good moral values such as cooperation, helping, sharing, sympathy, empathy, and needing one another.

Moral development in early childhood is the formation of moral behavior obtained by children through interaction with the environment both family, school, and society through imitation, modeling, and observation of children from the behavior of adults who become their idols and using social cognitive abilities [13]. Children are also not free from behavior formed by stimulation in the form of reward or punishment, through stimulation.

The environment of the microsystem gave direct influence on behavior for children through good interpersonal interactions from the environment [14]. Child moral development that is good will depend on the child's observation of the environment, especially the family. An environment that provides examples of unfavorable behavior to children and lacks support from their social environment will make children apathetic and withdrawn from a world that is not caring or even threatening so that children are unable to develop moral values well in their social environment.

Ref [15] concluded that parents who often give punishment in parenting could make children have problems in behaving. Parents must provide appropriate parenting patterns, when parents are more assertive and control children's activities and give punishment when children make mistakes; it will reduce children's behavior problems. If the action taken by a child against another person or peer gets a reward or an award from his parents, educator or social environment, then the child will tend to develop moral values which he thinks are good behavior. Conversely, if the child's actions to other people or their peers get an unpleasant punishment for him, then the child will try to abandon the behavior which he considers to be bad behavior. Also, imitation and stimulation obtained by children in their environment will be able to provide understanding to children about good and bad moral concepts.

Ref [16] concluded that in general children needed sufficient moral understanding. Children understood and developed moral values from the environment or place where children learned through the interaction of language with the surrounding environment. The development of children's moral values is the responsibility of the family, community, and educators. Therefore, families should to provide an understanding of moral values good and provide support to children to interact and organize moral values in the school, family and community environment, to develop motivation for children's moral values. Ref [17] concluded that the behavior of parents strongly influences children's character. The family has a very important role in developing a child's personality. The care of parents who are full of love and education about moral values, both religious and social are the main factors to prepare children to be good personal and healthy members of society.

Based on several theories and data obtained in the field, this research has the formulation of the problem, namely: How is the influence of authoritarian, authoritative and permissive parenting toward child's moral values development at Raudhatul Athfal, Murhum District, Baubau City.

\section{METHOD}

This research used a quantitative approach. The kind of this research is ex-post facto. It used to find the relationships that influence each other variables and are not manipulated or treatment in variables and data obtained in this research. Data analysis techniques in this research used statistical regression. This research was carried out at Raudhatul Athfal in Murhum District, Baubau City, RA Perwanida, RA Al -Amin, RA Baitul Hidayah, and RA Al-Mu'araf. The four schools are located in the center of Baubau City.

The population in this study were parents of students and students of group B Raudhatul Athfal in Murhum Subdistrict, Baubau City, with a total number of 150 parents and 150 students. As a sample [18].

The variables in this study are the type of parenting style (authoritarian, authoritative and permissive parenting) as independent variables $(\mathrm{X})$ and the development of children's moral values as dependent variables (Y).

Data collection techniques in this study were carried out by distributing questionnaires and observations in the learning process — data analysis techniques using simple regression analysis.

\section{RESULTS AND DISCUSSION}

\section{A. First Hypothesis Testing}

The first hypothesis showed that there was a negative influence on authoritarian parenting on the development of moral values of early childhood in Raudhatul Athfal throughout Murhum District, Baubau City. The results of testing the influence of authoritarian parenting on the 
development of early childhood moral values can be seen in the following regression coefficient table:

TABLE I. THE CORRELATION COEFFICIENT BETWEEN AUTHORITARIAN PARENTING WITH THE DEVELOPMENT OF CHILDREN'S MORAL VALUES.

\begin{tabular}{|l|l|l|l|l|}
\hline Model & \multicolumn{1}{|c|}{ R } & R Square & $\begin{array}{c}\text { Adjusted R } \\
\text { Square }\end{array}$ & $\begin{array}{c}\text { Std. The } \\
\text { error of the } \\
\text { Estimate }\end{array}$ \\
\hline 1 &, $428 \mathrm{a}$ & 0,183 & 0,151 & 8,23594 \\
\hline
\end{tabular}

TABLE II. REGRESSION COEFFICIENTS AUTHORITARIAN PARENTING ON THE DEVELOPMENT OF CHILDREN'S MORAL VALUES.

\begin{tabular}{|l|l|l|l|l|l|l|}
\hline \multirow{3}{*}{ Model } & \multicolumn{3}{|c|}{$\begin{array}{c}\text { Unstandardized } \\
\text { Coefficients }\end{array}$} & $\begin{array}{c}\text { Standardized } \\
\text { Coefficients }\end{array}$ & \multirow{2}{*}{ t } & \multirow{2}{*}{ Sig. } \\
\cline { 2 - 5 } & $\boldsymbol{B}$ & \multicolumn{2}{|c|}{ Std. Error } & Beta & & \\
\hline \multirow{2}{*}{1} & Constant & 28,632 & 22,323 & & 1,28 & 0,21 \\
\cline { 2 - 6 } & otoriter & 1,966 & 0,815 & 0,428 & 2,41 & 0,02 \\
\hline
\end{tabular}

Based on table 1 it could be seen that the correlation coefficient $(R)$ is 0.428 greater than $r$ table 0.374 . The correlation coefficient showed a positive and significant relationship between authoritarian parenting with the development of children's moral values. The $\mathrm{R} 2$ coefficient is 0.183 . The coefficient of determination shows that the development of moral values is explained by an $18.3 \%$ authoritarian parenting pattern. The regression coefficient is 1.966 with a significance of 0.02 less than 0.05 or sig. $<0.05$, it can be concluded that there was a positive and significant influence on authoritarian parenting on the development of early childhood values. This means that the higher the parents take care of with authoritarian parenting, then the moral values of children experience better development. Based on table 2, the calculation of cost and beta coefficients is generated, so that the regression equation can be made as follows:

$$
\hat{\mathrm{Y}}=28.632+1.966 \mathrm{X}
$$

The regression equation means that every increase in authoritarian parenting score is 1 unit number, so the development of children's moral values is predicted to increase 1.966 .

\section{B. Second Hypothesis Testing}

The second hypothesis showed that there was a positive influence on autorhythmic parenting on the development of moral values of early childhood in Raudhatul Athfal throughout Murhum District, Baubau City. The results of testing automatization parenting towards the development of early childhood moral values can be seen in the following regression coefficient table:

TABLE III. THE CORRELATION COEFFICIENT BETWEEN AUTHORITATIVE PARENTING WITH THE DEVELOPMENT OF CHILDREN'S MORAL VALUES.

\begin{tabular}{|l|l|l|l|l|}
\hline Model & \multicolumn{1}{|c|}{$\mathbf{R}$} & R Square & $\begin{array}{c}\text { Adjusted } \\
\text { R Square }\end{array}$ & $\begin{array}{c}\text { Std. The error of the } \\
\text { Estimate }\end{array}$ \\
\hline 1 &, $177 \mathrm{a}$ & 0,031 & 0,022 & 7,29453 \\
\hline
\end{tabular}

TABLE IV. REGRESSION COEFFICIENT AUTHORITATIVE PARENTING TOWARDS THE DEVELOPMENT OF CHILDREN'S MORAL VALUES.

\begin{tabular}{|c|c|c|c|c|c|c|}
\hline \multicolumn{2}{|c|}{ Model } & \multicolumn{2}{|c|}{$\begin{array}{c}\text { Unstandardized } \\
\text { Coefficients }\end{array}$} & $\begin{array}{c}\text { Standardized } \\
\text { Coefficients }\end{array}$ & \multirow{2}{*}{ t } & \multirow{2}{*}{ Sig. } \\
\cline { 3 - 6 } & $\boldsymbol{B}$ & $\begin{array}{c}\text { Std. } \\
\text { Error }\end{array}$ & Beta & & \multicolumn{1}{|c}{} \\
\hline \multirow{2}{*}{1} & (Constant) & 68,292 & 6,882 & & 9,923 & 0 \\
\cline { 2 - 6 } & autoritatif & 0,433 & 0,232 & 0,177 & 1,861 & 0,065 \\
\hline
\end{tabular}

Based on Table 3 it could be seen that the correlation coefficient $(R)$ is 0.177 less than $r$ table 0.195 . The correlation coefficient showed that there is a positive but not significant relationship between authoritative parenting and the development of moral values of early childhood. The R2 coefficient is 0.031 . The coefficient of determination shows that the development of moral values can be explained by authoritative parenting of $3.1 \%$ and a regression coefficient of 0.443 with a significance of 0.065 greater than 0.05 or sig. $0.065>0.05$, it could be concluded that there was a positive but not significant influence on authoritative parenting on the development of early childhood moral values. This means that the higher the parents care for with authoritative parenting, the children's moral values do not experience better development. Based on table 4, the calculation of cost and beta coefficients is generated, so that the regression equation can be made as follows:

$$
\hat{\mathrm{Y}}=68.292+0.433 \mathrm{X}
$$

The regression equation can be interpreted that, every increase in authoritative parenting score 1 unit of numbers, it is predicted that the development of children's moral values would increase by 0.433 . From the regression equation, it could be concluded that the research hypothesis is accepted, which means that authoritative parenting has a positive influence on the development of children's moral values.

\section{Third Hypothesis Testing}

The third hypothesis showed that there was a negative influence on permissive parenting on the development of early childhood moral values at Raudhatul Athfal in Murhum District, Baubau City. The results of permissive parenting testing on the development of early childhood moral values could be seen in the following regression coefficient table:

TABLE V. CORRELATION COEFFICIENTS BETWEEN PERMISSIVE PARENTING WITH THE DEVELOPMENT OF CHILDREN'S MORAL VALUES

\begin{tabular}{|l|l|l|l|l|}
\hline Model & $\mathbf{R}$ & R Square & $\begin{array}{c}\text { Adjusted } \\
\text { R Square }\end{array}$ & $\begin{array}{c}\text { Std. The error of } \\
\text { the Estimate }\end{array}$ \\
\hline 1 &, $473 \mathrm{a}$ & 0,223 & 0,153 & 5,80224 \\
\hline
\end{tabular}


TABLE VI. THE REGRESSION OF PERMISSIVE PARENTING TOWARDS THE DEVELOPMENT OF CHILDREN'S MORAL VALUES.

\begin{tabular}{|c|l|c|c|c|c|c|}
\hline \multicolumn{2}{|c|}{ Model } & \multicolumn{2}{|c|}{$\begin{array}{c}\text { Unstandardized } \\
\text { Coefficients }\end{array}$} & $\begin{array}{c}\text { Standardized } \\
\text { Coefficients }\end{array}$ & \multirow{2}{*}{ t } & \multirow{2}{*}{ Sig. } \\
\cline { 3 - 5 } & $\boldsymbol{B}$ & $\begin{array}{c}\text { Std. } \\
\text { Error }\end{array}$ & Beta & & \\
\hline \multirow{2}{*}{1} & Constan & 52,813 & 16,666 & & 3,169 & 0,009 \\
\cline { 2 - 6 } & permisif & 1,128 & 0,634 & 0,473 & 1,778 & 0,103 \\
\hline
\end{tabular}

Based on table 5 it could be seen that the correlation coefficient $(\mathrm{R})$ is 0.473 less than $\mathrm{r}$ table 0.553 . The correlation coefficient showed that there is a positive but not significant relationship between permissive parenting and the development of children's moral values - coefficient (R2). Of 0.223 the coefficient of determination shows that children's moral behavior is explained by a positive parenting pattern of $22.3 \%$ and a regression coefficient of 1.128 with a significant 0.103 greater than 0.05 or sig. $0.103>0.05$, it can be concluded that there is no significant effect of permissive parenting on the development of children's moral values. This means that the higher the parents take care of with the parenting style, then the moral values of the child do not experience better development. Based on table 6, the calculation of cost and beta coefficients is generated, so that the regression equation could be made as follows:

$$
\hat{\mathrm{Y}}=52.813+1.128 \mathrm{X}
$$

The regression equation means that every increase in permissive parenting score 1 unit of numbers, it is predicted that the development of children's moral values will increase by 1.128 . From the equation of the regression, it can be concluded that the research hypothesis is rejected, meaning there is no negative influence on permissive parenting on the development of moral values.

\section{Discussion}

The results of the first hypothesis test showed that there were a positive and significant relationship and influence between authoritarian parenting on the development of children's moral values. The results of the analysis are supported by the results of a descriptive analysis of the development of moral values that get an employee caregiver showing the development of moderate children's moral values with a percentage of $57.1 \%$. Authoritarian parenting has a good contribution to the development of children's moral values. Parents with authoritarian parenting could bring obedience, giving rules, controlling children and punishments adjusted to children's mistakes to achieve optimal moral values.

The results of this study are supported by research [19] who concluded the results of the statistical analysis t to $\mathrm{X}$ showed that the significance value is $0.000<0.05$. It means that authoritarian parenting contributes to the discipline of children aged 4 to 6 in Taman- Child Cluster 01 Ponorogo Sampung Tulung Regression coefficient is 6.159 , so it can be concluded that authoritarian parenting contributed positively to children's discipline.

While research [20], concluded that the authoritarian parenting style influenced children's discipline. Based on several other research results, it can be said that authoritarian parenting could have a positive impact on the development of children's behavior in certain areas. Parents of children at Raudhatul Athfal in Murhum District gave more authoritative parenting patterns and full control and limitations. Parents with this care have high hopes for their children. Behavioral boundaries are determined by parents, with the aim that children obedient to parents and those around them.

The same results were examined [21] concluding that mothers in mainland China maintain strong adherence to Chinese cultural values, so authoritarian parenting is the way the right to discipline children to conform to traditional moral codes, virtue, truth, decency, wisdom, and trust.

The high and low parenting patterns would largely determine the development of children's moral values. Parents who are less assertive, would make the childless well behaved, irresponsible, irreverent, not behaving honestly, not obedient to parents and those around him. The results of this study are also supported by research [22], concluding that parenting authoritarian parents could have a positive effect on children's moral behavior.

Authoritarian parenting is a parenting style that is firm, full of control in various children's activities, and provides punishment for children when they make mistakes. Parents are authoritarian when a child makes a mistake, hits a friend, takes someone else's goods, is rude to a more mature person. Through strict parenting that is applied by parents to children, children will develop good moral values, and obey parents as authorities. Ref [5] parents must have a strong position on moral authority that has the right to be respected and obeyed. With the behavior of an authoritarian parent, the child will obey his parents.

The results of the second hypothesis test showed that there is a positive but not significant relationship and influence between authoritative parenting with the development of children's moral values. This means that the higher the parents care with authoritative parenting, then the moral values of children do not experience better development. The results of the analysis were supported by the results of the descriptive analysis of the development of moral values that received authoritative parenting showed the development of moderate moral values with a percentage of $48.6 \%$.

These results indicated that the parenting style of authoritative towards the development of children's moral values regarding good communication turns out to have a positive. However, there is no significant influence, and the development of children's moral values is in the medium category, meaning parents who want to achieve good moral value development using good communication and providing opportunities for children, it turns out that it does not have a greater influence than authoritarian parenting. Ref [23] concluded that authoritative parenting could have a good influence on children's mentality. The parenting has the characteristics of parents who are warm, and always build good communication with children, to provide a good influence on children's development. Ref [8] concluded that authoritative parenting had a positive influence on children's emotional and behavioral problems. Parents implemented authoritative care in 
Murhum District regarding building good communication, to achieve the optimal development of children's moral values. Authoritative parenting does not make a greater contribution to strict parenting patterns, with over control children.

The results of the third hypothesis test show that there are a positive relationship and influence but not significant between permissive parenting towards the development of moral values of early childhood. This means that the higher the parents care for with permissive parenting. So the moral value of children does not experience better development. The results of the analysis are supported by the results of the descriptive analysis of the development of moral values that get permissive parenting shows the development of moderate moral values with a percentage of $53.8 \%$.

It can be seen that parenting permissive parents towards the development of children's moral values regarding no restrictions for children turns out to have a positive but insignificant influence, meaning parents can apply permissive parenting to maximize the development of children's moral values. However, by using this permissive parenting style, if parents are too spoiled children, then the development of moral values of early childhood will not optimally develop because it does not have a significant influence.

Permissive parenting has a significant relationship and influence from authoritarian parenting. Permissive parents have characteristics that tend to provide freedom and are permissible in children's activities. Authoritarian parenting provided a positive influence on the development of children's moral values in Murhum District, Baubau City. Research [24], concluded that parents in Turkey, it provides a more nurturing pattern of parenting. But it does not have significant influence if parents apply permissive parenting regarding giving freedom, to achieve the optimal development of children's moral values. This parenting pattern does not provide a greater contribution than a strict parenting pattern, with control over children.

In each particular region have different parenting styles. Ref [14] said the macrosystem environment influences human development, which is based on different ethnicities and cultures. Thus the behavior of parents can influence the development of children's moral values depending on the background of parents, namely in the form of different social, ethnic, cultural status. A good parenting pattern that suits the child's condition and environment and culture in a particular place will have a good influence on the development of children's moral values.

Parenting style at Murhum's Raudhatul Athfal District had a better influence with authoritarian parenting than authoritative and perceptive parenting. Parents emphasize this pattern of affirmation because it is more assertive, and controls children in the hope of making children who are obedient, responsible, behave honestly, polite, respect for others, obedient to parents and people around him. The results of this study are supported by research [25], concluded that authoritarian parenting is very influential and supportive in improving children's morale, although this parenting model is strict, and strictly controlled in various children's interactions, but could improve behavior. Moral and obedient to family rules. Authoritarian parenting is strict and full of control over various activities of the child, so that children who grow and develop in a family with a tendency to parenting, could improve good moral values. Namely, the child became responsible, polite, behave honestly, sportsmanly and obedient towards parents and those around them.

Parenting patterns that are applied in a family environment both authoritarian, authoritative, and permissive parenting can have a positive influence on the development of children's moral values, through various activities between parents and children. Ref [26] concluded the pattern of family communication in the city of Bekasi in settlements and settlements, is a communication pattern carried out in a combination of laissez-faire and protective communication, between pluralistic and consensual. When children choose to play and choose friends, active socialization is carried out in recognition of social values. Parents, of course, apply forms of care that are appropriate to the conditions and behavior of children. When children always do bandages that are not good at violating moral values, of course, parents must be firm, and disciplined so that children leave unfavorable actions, on the contrary children must be given the freedom to develop their potential, learn independently, and be responsible, actualize their potential, build good relationship with peers. Ref [12] explained the method chosen by parents as a method of children's education, namely authoritarian, permissive or authoritative would depend on the way and experience of parents in educating their children. Therefore, a good way of caring for parents could motivate children to shape their personality into children who have moral values that are by the moral code in their social environment.

\section{CONCLUSION}

There was a positive and significant influence of authoritarian parenting toward child's moral values development of group B at Raudhatul Athfal, Murhum District, Baubau City. It meant that the higher parents take care of with authoritarian parenting, the children's moral values could develop very well. Authoritarian patterns gave greater influence than authoritative and permissive parenting. There was a positive but not significant influence on authoritative parenting on the development of the moral values of early childhood group B at Raudhatul Athfal, Murhum District, Baubau City. This means that the higher the parents care for with authoritative parenting, the children's moral values do not experience better development. There was a positive but not significant influence on permissive parenting on the development of the moral values of early childhood group B at Raudhatul Athfal, Murhum Subdistrict, Baubau City. It meant that the higher the parents care for with permissive parenting, the children's moral values do not experience better development.

\section{REFERENCES}

[1] H. Haryanti and S. Sumarno, "Pemahaman Kompetensi Parenting Terhadap Perkembangan Sosial Anak (Studi Kasus Pada Kelompok Bermain di Pakem, Sleman)," Jurnal Pendidikan dan Pemberdayaan Masyarakat, vol. 1, no. 1, p. 32, March 2014. 
[2] G.S. Morison, Early Childhood Education Today, $4^{\text {th }}$ Ed, Melbourne: Merrill Publishing Company, 1988.

[3] M. A. Wong, "Perception of parental involvement and autonomy: Their relation with self-regulation, academic performance, substance, use the resilience among adolescents," North America Journal of psychology, vol. 10, p. 497-518, 2008 .

[4] L. Madyawati, "Pengembangan bahasa pada anak," Jakarta : Prenadamedia Group, 2016.

[5] T. Lickona, "Pendidikan karakter panduan lengkap mendidik siswa menjadi pintar dan baik," Bandung: Nusa Media, 2013.

[6] J. W. Santrock, Life-span development jilid 3, New York: McGrawHill, 2012.

[7] J. G. Querido et al, "Parenting Style and Child Behavior in Africa Families of Preschool Children," Journal of Clinical Child Psychology, Vol. 31, No. 2, p. 272-277, 2002.

[8] C. Marja, "Parenting Style as a Mediator Between Children's Negative Emotionality and Problematic Behavior in Early Childhood," The Journal of Genetic Psychology, vol. 169, No. 3, p. 209-226, 2008.

[9] P. D.Ningsih, "Pola asuh kaum bangsawan lalu-baiq dalam membentuk karakter anak di desa padamara lombok timur," Jurnal Harmoni Sosial, vol. 1 no. $2,2014$.

[10] T. Tavassolie, "Differences in Perceived Parenting Style Between Mothers and Fathers: Implications for Child Outcomes and Marital Conflict," J Child Fam Studio Vol. 25, p. 2055-2068, 2016.

[11] J. Huang, and L. Prochner, "Chinese Parenting Styles and Children's Self-Regulated Learning," Journal of Research in Childhood Education, vol 18, no.3, 2004.

[12] E. B. Hurlock, Perkembangan anak.Jilid 1, Jakarta : Erlangga, 1978.

[13] J. W. Santrock, Perkembangan anak, Jakarta: Erlangga, 2007.

[14] U. Bronfenbrenner, The Ecology of human development experiments by nature and design, United State of America: Harvard University Press, 1979.

[15] M. R. L. Lewis, "Early Childhood Externalising Behaviour Problems: Child, Parenting, and Family-related Predictors Over Time," Journal of Abnormal Child Psychology, vol. 34, no. 6, pp. 886-901, Nov. 2006.

[16] G. Nunner and Winker, "Development of moral motivation from childhood to early adulthood", Journal Of Moral Education, vol. 36, no.4, p. 399-414, 2007.
[17] M. A. Claridge and A. S. Wojciak, "Reciprocal associations among maternal and child characteristics of at-risk families: a longitudinal actor-partner interdependence model" Journal of Marital and Family Therapy, Vol. 41, no. 3, p. 308-32, 2015.

[18] S. Sugiyono, Metode penelitian pendidikan pendekatan kuantitatif, kualitatif dan R \& D, Bandung: Alfabeta, 2015.

[19] D. E. Pramesti and N. Khotimah,"Pengaruh pola asuh otoriter terhadap kedisiplinan anak usia 4-6 tahun," Jurnal Paud Teratai, Vol. 05, no. 03, p. 187-190, 2016.

[20] A. Thompson, Hollis and D. Richards, "Authoritarian parenting attitudes as a risk for conduct problems," European Child \& Adolescent Psychiatry, vol. 12, no. 2, pp. 84-91, Apr. 2003.

[21] Y. Xu, et al, "Mainland Chinese parenting styles and parent-child interaction," International Journal of Behavioral Development, vol. 29, no.6, p. 524-531, 2005.

[22] L. R. Williams, et al, "Impact of behavioral inhibition and parenting style on internalizing and externalizing problems from early childhood through adolescence," Journal Abnorm Child Psychol, vol 37, 2009.

[23] F. R. Niaraki and H. Rahimi,"'The impact of authoritative, permissive and authoritarian behavior of parents on self-concept, psychological health, and life quality," European Online Journal of Natural And Social Sciences, vol.2, No.1, p. 78-85, 2013.

[24] V. Nauck and B. Lotter. "Parenting styles and perceived instrumentality of schooling in native, Turkish, and Vietnamese families in Germany," Zeitschrift für Erziehungswissenschaft, vol. 18, no. 4, pp. 845-869, May 2015 .

[25] R. Karmakar, "Does Parenting Style Influence the Internalization of Moral Values in Children and Adolescents?," Psychological Studies, vol. 60, no. 4, pp. 438-446, Nov. 2015.

[26] A. Sari, "Pengaruh Pola Komunikasi Keluarga dalam Fungsi Sosialisasi Keluarga terhadap Perkembangan Anak," Jurnal Komunikasi Pembangunan, vol. 08, No. 2, 2010. 